\title{
Perspectives on Salutogenesis of Scholars Writing in German: Contributions from Switzerland
}

\author{
Claudia Meier Magistretti and Sarah Auerbach
}

\section{Introduction}

This chapter focuses on Swiss salutogenesis publications in German. English publications by Swiss-German authors are mentioned but not systematically included in this overview. The identification of relevant research was done using national databases of ongoing or completed research projects (e.g., FORS, ARAMIS, and Swiss National Science Foundation), a project-database held by different Universities of Switzerland (http://www.forschungsportal.ch), as well as publication databases (e.g., PsychInfo and Medline), and several university databases and public libraries (e.g., Swissbib).

\section{Salutogenesis as a Research Field in the German-Speaking Part of Switzerland}

Like Swiss health research in general, research on salutogenesis is broad and wide-ranging, and characterized by a lack of coordination and cooperation. Salutogenic research is undertaken at the initiative of individual researchers, and there seem to be no organizational units that focus on salutogenesis. No conferences on salutogenesis or applied research in this field have been held, although some conferences include a salutogenic orientation (GAIMH, 2000; Hochschule Luzern, 2012; White, Schouten, Berg, \& Meier Magistretti, 2014). The Swiss National Science Foundation has thus far not funded a national program on salutogenesis, but several research projects addressing salutogenesis have received financial support (Götzmann et al., 2012; Gutzwiller \& Wydler, 2005;

C.M. Magistretti $(\bowtie) \bullet$ S. Auerbach

Center for Prevention and Health Promotion, Institute of Social

Management, Social Policy and Prevention, Lucerne University of Applied Sciences and Arts, Lucerne, Switzerland

e-mail: claudia.meiermagistretti@hslu.ch; sarah.auerbach@hslu.ch
Rimann \& Udris, 1997). In contrast to other areas of health research (e.g., gender health and occupational health) there is no network for salutogenic research. Instead, several networks on various topics such as wellness or self-healing programs claim to have a salutogenic orientation or refer to Aron Antonovsky's work (not always accurately).

Yet, salutogenesis is indeed of academic interest in German-speaking Switzerland, with the more than 80 publications published over the last years spanning four themes:

- Theory development

- Texts about the application of salutogenesis in public health

- Research having a salutogenic orientation in a general sense

- Research having a salutogenic orientation with a specific focus on the sense of coherence

The first-even though the smallest-group of researchers is involved with salutogenic theory itself, developing salutogenic thinking, integrating new concepts, or adopting salutogenic theory to new fields. Abel and colleagues combined salutogenesis with concepts of Nussbaum and Sen's capability approach (Nussbaum \& Sen, 1993) showing how a salutogenic capability approach could contribute to increase equality in health (Abel, Abraham, \& Sommerhalder, 2009; Abel \& Frohlich, 2012; Abel, Fuhr, \& Spörri, 2007; Abel \& Schori, 2009). Other authors link salutogenesis to sustainable development (Anliker, 2013) or apply it to practical fields of health promotion and addiction (Wettstein, 2008, 2009, 2014), with the considerable effect that National Policy Papers on health promotion (Mattig, 2014) and migrant health (BAG, 2007) are partly or entirely and explicitly based on salutogenic theory.

The second group of publications consists of entire text books, chapters in text books, and journal articles explaining salutogenic theory to specific groups of professionals in 
Fig. 41.1 Research activities in health fields generally and with an explicit salutogenic focus (based on the schema of Bänziger et al., 2011 and on the research presented in this chapter)
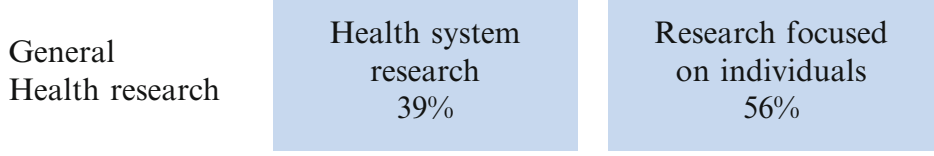
Health research with an explicit salutogenic orientation

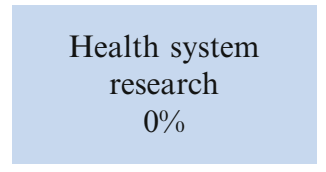

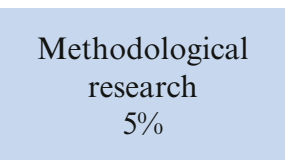

Research focused on individuals $92 \%$
Methodological research $8 \%$

public health (Egger \& Razum, 2014; Wydler, Kolip, \& Abel, 2000; Zeyer, 1997), nursing (Pielot, 2009), midwifery and early life care (Hungerbühler-Räber \& KellerSchuhmacher, 2003; Keller-Schuhmacher, 2004; Meier Magistretti \& Luyben, 2012), psychotherapy (Fäh, 2004; Schlegel, 2004), or providing professional tools for salutogenic practice for teachers (Brägger \& Posse, 2007; Märki et al., 2005).

A third group represents research projects taking the salutogenic perspective. Their authors refer either generally to Antonovsky's salutogenic model (Fabian, 2012), use salutogenesis as a theoretical framework for their research (Süss et al., 2002).

The last and largest group of researchers uses the sense of coherence scale in projects with a general salutogenic orientation (e.g., Buddeberg-Fischer, Klaghofer, Leuthold, \& Buddeberg, 2000; Gutzwiller \& Wydler, 2005).

As illustrated in Fig. 41.1, salutogenic research is mostly focused on the health of groups and individuals, as well as some methodological research, but the salutogenic perspective is not yet applied to health system research.

\section{Occupational Health}

There has been a clear focus on salutogenesis in the field of occupational health at ETH Zurich-partly in cooperation with the Universities of Zurich and Berne. Starting in the early 1990s with a large research program named SALUTE, Yvan Udris and his colleagues followed the salutogenic approach and Aaron Antonovsky's health theory integrating the tradition of personality and health promoting humane job design with the tradition of salutogenesis (Udris, 1990, 1993, 2006; Udris, Kraft, Muheim, Mussmann, \& Rimann, 1992; Udris, Kraft, Muheim, \& Mussmann, 1992; Udris, Rimann, \& Thalmann, 1994). A Salutogenic Subjective Job-Analysis questionnaire-SALSA — was developed based on qualitative research of factors contributing to the health of healthy workers (Kraft, Udris, Mussmann, \& Muheim, 1994; Rimann \& Udris, 1997; Udris \& Rimann, 1999).

The SALSA questionnaire has been widely used in various contexts of occupational health and health promotion. Related publications cover a broad range including national survey reports on occupational health (Hämmig et al., 2005), healthy working conditions in universities (Zölch et al., 2005), and health promotion programs of national insurance companies (Udris \& Rimann, 1999). The SALSA questionnaire has been adopted by labels for health promoting companies. These labels can be applied for by companies in Switzerland who gain in compensation the title "friendly work space" that allows them an advantage on the labor market as well as an image gain for their companies (Arbeitsgruppe BGM-Kriterien, 2012). SALSA has been adopted also in public administration and in many smaller organizations (e.g., Schwendimann, 2013).

A special issue of the National Journal on Business Psychology (Wehner \& Richter, 2006) provided an overview of the SALUTE and of related studies (e.g., Reuter, 2006 on salutogenesis and participation and Semmer, Jacobshagen, \& Meier, 2006 on sense of coherence and stress, Bauer \& Schmid, 2006 on salutogenic interventions in organizations). A salutogenic orientation in occupational health research has been taken in other contexts, such as teacher's health and well-being (Herzog, 2007), and national surveys on psychological and occupational health (Moreau-Gruet, 2013).

Salutogenic occupational health research experienced a new and strong emphasis through the work of Georg Bauer and his group at the University of Zurich. Although the main volume as well as following publications were published in English (Bauer \& Jenny, 2013), his salutogenic approach, focusing on resources and positive outcomes of healthoriented organizational change processes, considerably influenced occupational health research as well as education in the German-speaking part of Switzerland. The group developed a work-related sense of coherence questionnaire (Work-SOC) measuring the perceived comprehensibility, manageability, and meaningfulness of an individual's current work situation on a nine items scale (Vogt, Jenny, \& Bauer, 2013; Bauer, Vogt, Inauen, \& Jenny, 2015). The concept and the instrument of work sense of coherence are currently applied in a longitudinal study that is systematically testing the different roles of the sense of coherence in the motivational process of the job demands-resources model in a national program for stress prevention and stress management at work (Jenny et al., 2011). 


\section{Salutogenesis in Medical Research}

Medical research has traditionally been oriented toward pathology and risk avoidance in Switzerland as well as in many other countries. However, there is an ongoing tradition of salutogenic perspectives in medical research, focusing mainly on topics of coping with injuries, trauma, and surgery. At the University Hospital of Zurich, Schnyder and his group conducted a longitudinal study on psychosocial coping with posttraumatic stress disorder in patients experiencing severe injuries. They adopted a general salutogenic orientation and used the sense of coherence scale as an outcome measure (Schnyder 2000). Posttraumatic stress symptoms did not correlate with injury severity but with pretraumatic stressors, the patients' subjective appraisal of the accident, their current coping pattern, and with their sense of coherence. The authors also found that traumatic events such as life-threatening accidents may change a person's sense of coherence, even if psychiatric symptoms abate (Schnyder, Moergeli, Klaghofer, \& Buddeberg, 2001; Schnyder, Moergeli, Trentz, Klaghofer, \& Buddeberg, 2001; Schnyder, Moergeli, Klaghofer, Sensky, \& Buchi, 2003), but that sense of coherence has no predicting value for the development of posttraumatic stress disorders after severe injuries (Hepp, Moergeli, Buchi, Wittmann, \& Schnyder, 2005; Wittmann, Moergeli, MartinSoelch, Znoj, \& Schnyder, 2008). The relationship of sense of coherence to the psychosocial effects of health problems was confirmed by the same group of authors in patients with rheumatic rheumatoid arthritis (Schnyder, Büchi, Mörgeli, Sensky, \& Klaghofer, 1999). Recently, members of this group focused on the role of the sense of meaningfulness in coping processes with trauma after the 2004 Tsunami (Kraemer, Wittmann, Jenewein, Maier, \& Schnyder, 2009).

In parallel, research at the University of Berne used the sense of coherence scale in research on coping strategies and environmental resources in patients adjusting to spinal cord injury (Znoj \& Lude, 2002). Also investigating sense of coherence and trauma, but focusing on a healthy population group, Sommer and colleagues concluded to the contrary to Znoj's results that in their sample of Swiss mountain guides, sense of coherence did not predict, but seemed rather to be a marker for psychological health (Sommer \& Ehlert, 2004).

The sense of coherence scale has also been used in studies of transplant patients, showing a strong positive correlation of strong sense of coherence with patients' positive attitudes toward their medication, their perceived self, and their fate (Götzmann, 2008). A comparable picture was found with the patients' spouses, except for a negative correlation between the sense of coherence and the attitude toward the transplantation in terms of stress and anxiety (Götzmann et al., 2012).

A study conducted on patients with morbid adiposities undergoing a gastric banding operation showed a weak sense of coherence in patients both with and without an additional psychiatric diagnosis, but no predictive power of the sense of coherence on the quality of life and eating behavior after surgery (Lang, Hauser, Schlump, Klaghofer, \& Buddeber, 2000).

In studies on patients with somatoform disorders and on the elderly, the sense of coherence was measured, but no results were reported (Buddeberg, Klaghofer, Nigg, \& Steurer, 2001).

A general salutogenic orientation underpinned studies on nonspecific low back pain. Rolli-Salathé \& Elfering described these patients' resources regarding life management, working ability, and pain control (Rolli-Salathé \& Elfering, 2013) and Tamcan and colleagues developed and tested a 12-item scale based on the three dimensions of the sense of coherence (Tamcan, Bantli, Abel, \& Barth, 2010). The scale serves as an assessment tool of patients' resources in clinical practice.

A last branch of salutogenic research in medicine addresses the role of medical doctors, their working conditions, and health. Buddeberg-Fischer, Klaghofer, Abel, and Buddeberg (2006) addressed the question whether the sense of coherence was associated with the specializations young doctors chose. They found that although sense of coherence varies among different medical disciplines, gender is-at least in Switzerland-the decisive determinant for professional careers of young doctors (ibid). A prospective cohort study conducted by the same authors confirmed the stress-buffering effect of a strong sense of coherence among medical students and young doctors in their early professional career (Buddeberg-Fischer et al., 2008, 2009; Buddeberg-Fischer, Stamm, Buddeberg, \& Klaghofer, 2009).

\section{Salutogenesis in Research on Health Promotion}

Health and health promotion over the life span are among the main areas of health research in German-speaking Switzerland (Meyer, 2009). The practical implications of a general salutogenic orientation have been discussed in terms of Antonovsky's theory for more than 10 years (HungerbühlerRäber \& Keller-Schuhmacher, 2003; Keller-Schumacher, 2004; 2005; Hafen, 2012). Though, in maternity care as well as in early life support and education of children, salutogenesis has just started to be an explicit focus in research (Meier Magistretti \& Luyben, 2012). A salutogenic orientation has been fostered in the Swiss public health position paper on early childhood health (Public Health Schweiz, 2012). But research in this area has not gone beyond a general health orientation in the sense that resources and positive health outcomes became research interests. 
For school-age children, salutogenic research was more extensive in the 1990s, when the group of BuddebergFischer investigated the associations among body image, sense of coherence and well-being among more than 500 high school students. They found strong correlations between the sense of coherence, well-being, body image, and concerns about eating behavior and bodily self (Buddeberg-Fischer et al., 2001). This research group has also observed a significant influence of high school climate on sense of coherence and other indicators of students' health and well-being (Buddeberg-Fischer, 2000; Buddeberg-Fischer et al., 2000). Bolliger-Salzmann (1997) adopted the sense of coherence scale in a study showing that a school-based health-promoting program reached and benefitted the teenagers most in need-the ones with the weakest sense of coherence.

Later, sense of coherence and selected general resistance resources were used as indicators evaluating the schoolbased health promotion program entitled "fit and stong" (Jurt \& Niewenboom, 2004). Next, Gutzwiller and his group conducted a large retrospective comparative study on 20,000 adolescents. They observed that favorable styles of parental education were associated with stronger adolescent sense of coherence (Gutzwiller \& Wydler, 2005; Wydler et al, 2007). In the last few years, the salutogenic orientation in school-based health research has been reduced to a few general statements indicating that research projects should follow a salutogenic view, without explicitly adopting salutogenic theory (Fäh, 2009; Dubowicz et al., 2013).

As described above, salutogenic research on adulthood has been focusing mostly on issues related to work place health and medical studies. Research on the elderly has been selectively undertaken in the past 10 years. There, a similar pattern is noted: a salutogenic view is promulgated (Duetz \& Bähler, 2006; Herrmann, 2007; Stamm et al., 2014), but not clearly put into methodological practice. An exception was found in a study of spiritual needs as one dimension of the sense of meaningfulness (Zwinggi et al., 2006). However, the study investigated the professionals' spiritual needs and competences in a home for the elderly and not the needs of the elderly themselves.

\section{Salutogenic Research in Psychiatry and Psychotherapy}

A small number of projects with a salutogenic orientation have been published in the area of psychotherapy and psychiatry. A study conducted with children of parents with a psychiatric disorder used the sense of coherence scale as one of several elements to describe identity formation of children in these families (Sollberger et al., 2007). Meister and Haug (2004) used the sense of coherence scale as a control to validate a questionnaire measuring health in schizophrenic patients. Schlegel (2004) described parallels of Antonovsky's sense of meaningfulness and the dimensions of sense and meaning in Jungian psychotherapy. One study included the sense of coherence in a longitudinal study on the effectiveness of systemic psychotherapy in patients suffering from anorexia nervosa and showed that the level of sense of coherence significantly increased over the relatively short time of 19 therapy sessions (Grünwald et al., 2013).

\section{Future Perspective}

The number of studies adopting the sense of coherence or other relevant aspects of salutogenic theory was surprising, considering that salutogenesis is virtually nonexistent in both the public academic discussion on health and the basic education of academic staff (outside of the professions very closely linked to the healthcare system). Additionally, there seem to be even more Master and Bachelor's theses related to salutogenic theory than research projects. This suggests that the interest of the coming academic generation in salutogenesis is strong-stronger perhaps than the responses the young researchers might find in the academic system. Switzerland-or at least the German-speaking part of it-would be well advised to foster this interest and to support these rising initiatives by adequate models of networking, mentoring and coaching.

Open Access This chapter is distributed under the terms of the Creative Commons Attribution-Noncommercial 2.5 License (http:// creativecommons.org/licenses/by-nc/2.5/) which permits any noncommercial use, distribution, and reproduction in any medium, provided the original author(s) and source are credited.

The images or other third party material in this chapter are included in the work's Creative Commons license, unless indicated otherwise in the credit line; if such material is not included in the work's Creative Commons license and the respective action is not permitted by statutory regulation, users will need to obtain permission from the license holder to duplicate, adapt or reproduce the material.

\section{References}

Abel, T., Abraham, A., \& Sommerhalder, K. (2009). Kulturelles Kapital, kollektive Lebensstile und die sozialer Reproduktion gesundheitlicher Ungleichheit. In M. Richter \& K. Hurrelmann (Eds.), Gesundheitliche Ungleichheit: Grundlagen, Probleme, Perspektiven (pp. 195-208). Wiesbaden: VSA Verlag für Sozialwissenschaften.

Abel, T., \& Frohlich, K. L. (2012). Capitals and capabilities: Linking structure and agency to reduce health in equalities. Social Science \& Medicine, 74(2), 236-244.

Abel, T., Fuhr, D., \& Spörri, A. (2007). Gesundheitliche Ungleichheit und Armut: Konzeptionelle Anmerkungen und empirische Ergebnisse zum Zusammenspiel von materiellen und immateriellen 
Ressourcen. In U. Renz \& B. Bleisch (Eds.), Armut (pp. 252-273). Zürich: Seismo-Verlag.

Abel, T., \& Schori, D. (2009). Der Capability-Ansatz in der Gesundheitsförderung: Ansatzpunkte für eine Neuausrichtung der Ungleichheitsforschung. Österreichische Zeitschrift für Soziologie, 34(2), 48-64. doi:10.1007/s11614-009-0012-9.

Anliker, S. (2013). Gesundheit als Teil von Bildung für Nachhaltige Entwicklung BNE. Positionspapier im Auftrag des Bundesamts für Gesundheit, FHNW, Soziale Arbeit. Olten

Arbeitsgruppe BGM-Kriterien. (2012). Wegleitung Qualitätskriterien für das Betriebliche Gesundheitsmanagement, BGM-Kriterien 1-6. Bern: Gesundheitsförderung Schweiz.

BAG, Bundesamt für Gesundheit. (2007). Strategie migration und Gesundheit (Phase II: 2008-2013). Bern: Bundesamt für Gesundheit.

Bänziger, A., Treusch, Y., Rüesch, P., \& Page, J. (2011). Gesundheitsforschung in der Schweiz-Thematische Schwerpunkte, institutionelle Verankerung. Eine Standortbestimmung im Auftrag der Schweizerischen Akademie der Geistes- und Sozialwissenschaften. Zürich; Zürcher Hochschule für angewandte Wissenschaften ZHAW.

Bauer, G. F., \& Jenny, G. J. (Eds.). (2013). Salutogenic organizations and change: The concepts behind organizational health intervention research. Dordrecht: Springer.

Bauer, G., \& Schmid, M. (2006). Betriebliches Gesundheitsmanagement als salutogene Intervention. Entwicklungsstand und Potenzial im Schweizer Dienstleistungssektor. Wirtschaftspsychologie, 2/3, 47-55.

Bauer, G., Vogt, K., Inauen, A., \& Jenny, G. J. (2015). Work-SoCEntwicklung und Validierung einer Skala zur Erfassung des arbeitsbezogenen Koharenzgefühl. Zeitschrift für Gesundheitspsychologie, 23(1), 20-30.

Bolliger-Salzmann, H. (1997). Bedingungen von Jugendlichen zum Teilnahmeentscheid an einem Gesundheitsförderungsangebot in der Schule, Unpublished doctoral dissertation. University of Bern, Switzerland.

Brägger, G., \& Posse, N. (2007). Instrumente für die Qualitätsentwicklung und Evaluation in Schulen IQES. Wie Schulen durch eine integrierte Gesundheits-und Qualitätsförderung besser werden können. Bern: h.e.p.-Verlag.

Buddeberg, C., Klaghofer, R., Nigg, C., \& Steurer, J. (2001). Behandlungsverläufe bei Patienten mit somatoformen Störungen. Zeitschrift für Medizinische Psychologie, 2, 87-93.

Buddeberg-Fischer B. (2000). Macht Schule krank? Möglichkeiten der Gesundheitsförderung in der Schule. In Th. Plenge (Hrsg.) Salutogenese-Was hält gesund? (pp. 23-40). Regensburg: Roderer.

Buddeberg-Fischer, B., \& Klaghofer, R. (2002). Entwicklung des Körpererlebens in der Adoleszenz. Praxis der Kinderpsychologie und Kinderpsychiatrie, 51, 697-710.

Buddeberg-Fischer, B., Klaghofer, R., Abel, T., \& Buddeberg, C. (2006). Swiss residents' speciality choices-Impact of gender, personality traits, career motivation and life goals. BMC Health Services Research, 6(137), 1-9. doi:10.1186/1472-6963-6-137.

Buddeberg-Fischer, B., Klaghofer, R., Leuthold, A., \& Buddeberg, C. (2000). Unterrichtsklima und Symptombildungen. Zusammenhänge zwischen Schulstress, Kohärenzgefühl und physischen/psychischen Beschwerden von Gymnasiasten. Psychotherapie, Psychosomatik, Medizinische Psychologie, 50, 222-229.

Buddeberg-Fischer, B., Stamm, M., Buddeberg, C., Bauer, G., Hämmig, O., \& Klaghofer, R. (2008). Arbeitsstress, Gesundheit und Lebenszufriedenheit junger Ärztinnen und Ärzte. Deutsche Medizinische Wochenschrift, 133(47), 2441-2447. doi:10.1186/ 1472-6963-6-137.
Buddeberg-Fischer, B., Stamm, M., Buddeberg, C., \& Klaghofer, R. (2009). Angst und Depression bei jungen Ärztinnen und Ärzten-Ergebnisse einer Schweizer Longitudinalstudie. Zeitschrift für Psychosomatische Medizin und Psychotherapie, 55 (1), 37-50. doi:10.13109/zptm.2009.55.1.37.

Dubowicz, A., Camerini, A.-L., Ludolph, R., Amann, J., \& Schulz, P. J. (2013). Bewegung und Ernährung an Schweizer Schulen, Ergebnisse der zweiten Befragung von Schulleitungspersonen in der Schweiz und im Fürstentum Liechtenstein. (Gesundheitsförderung Schweiz, Arbeitspapier 10). Retrieved from Gesundheitsförderung Schweiz website http://gesundheitsfoerderung.ch/assets/ public/documents/1_de/d-ueber-uns/5-downloads/Arbeitspapier_ 010_GFCH_2013-10_-_Bewegung_und_Ernaehrung_an_ Schweizer_Schulen.pdf.

Duetz Schmucki, M., \& Bähler, G. (2006). Altern in Gesundheit. In Bundesamt für Gesundheit (Ed.) Gender-Gesundheitsbericht Schweiz 2006. Grundlagen zur Entwicklung von forschungs- und handlungsbezogenen Aktivitäten (pp. 107-118). Bern: Bundesamt für Gesundheit BAG.

Egger, M., \& Razum, O. (Eds.). (2014). Public Health: Sozial- und Präventivmedizin Kompakt (2nd ed.). Berlin: De Gruyter.

Fabian, C. (2012). Situationsanalyse und Bedarfserhebung: Gesundheitsförderung, Prävention und Früherkennung an den Solothurner Schulen (Research report). Retrieved from Kanton Solothurn website: http://www.so.ch/fileadmin/internet/ddi/igsaa/ praevention_kt_so/20120503_GF_P_SchulenKtSO_Def_FHNW_ ISS.pdf.

Fäh, M. (2004). Psychotherapie und Salutogenese: Überlegungen zum theoretischen und praxeologischen Brückenschlag. Psychotherapie Forum, 12, 3-15.

Fäh, B. (2009). Starke Eltern-Starke Lehrer-Starke Kinder. Wie die psychische Gesundheit von Eltern und Lehrern Kindern hilft. Marburg: Tectum.

GAIMH. (2000). Salutogenese im Frühbereich: ErfahrungenKonzepte-Konsequenzen. Symposium der Gesellschaft für die seelische Gesundheit in der frühen Kindheit GAIMH, Zürich: 24. - 26- Februar . Retrieved from https://www.yumpu.com/.../ grundlagen-ag-salutogenese-im-fruhbereich.

Götzmann, L. (2008). Psychologische Aspekte der Organtransplantation. Zur Lebensqualität und Lebenszufriedenheit von Transplantationspatienten. Bern: Schweizerische Gesellschaft für Gesundheitspolitik.

Götzmann, L., Scholz, U., Dux, R., Roellin, M., Boehler, A., Muellhaupt, B., et al. (2012). Life satisfaction and burnout among heart, lung, liver, and kidney transplant patients and their spouses. Swiss Journal of Psychology, 71, 125-134. doi:10.1024/1421-0185/ a000079.

Grünwald, H., Stauffacher, K., Otafin Hermann, K., \& Liechi, J. (2013). Ergebnisqualität ambulanter systemischer Therapie bei Anorexie. Eine Praxisstudie zur Wirksamkeit der systemisch orientierten Therapie im ambulanten Setting. Familiendynamik, 38(1), 52-61.

Gutzwiller, F., \& Wydler, H. (2005). Elterliche Erziehungsstile und Eltern-Kind-Beziehungen: Ihr Einfluss auf die Gesundheit der Kinder und ihr Wandel im Laufe der Zeit. Wissenschaftlicher Schlussbericht NFP 52. . Zürich: unveröffentlicht.

Hafen, M. (2012). Better together-Prävention durch Frühe Förderung. Präventionstheoretische Verortung der Förderung von Kindern zwischen 0 und 4 Jahren. Luzern: Hochschule LuzernSoziale Arbeit.

Hämmig, G., Jenny, O., \& Bauer, G. (2005). Arbeit und Gesundheit in der Schweiz. Surveybasiertes Monitoring der Arbeitsbedingungen und des Gesundheitszustandes der Schweizer Erwerbsbevölkerung. Arbeitsdokument des Obsan 12, Neuenburg: Bundesamt für Statistik. 
Hepp, U., Moergeli, H., Buchi, S., Wittmann, L., \& Schnyder, U. (2005). Coping with serious accidental injury: A one-year follow-up study. Psychotherapy and Psychosomatics, 74, 379-386.

Hermann, M. L. (2007). Narrative Gerontologie. Ein Literatur-und Forschungsbericht. Psychotherapie und Sozialwissenschaft, 9(1), 7-32.

Herzog, S. (2007). Beanspruchung und Bewältigung im Lehrerberuf. Eine salutogenetische und biografische Untersuchung im Kontext unterschiedlicher Karriereverläufe. Münster: Waxmann.

Hochschule Luzern. (2012). Ein gesunder Start ins Leben. Salutogenese und Gesundheit rund um Geburt und frühe Mutterschaft.Tagung im Rahmen der COST-Aktion IS0907., Licerne, April 26th. Retrieved from http://www.hslu.ch/ sozialearbeit/s-veranstaltungen/s-kongresse-archiv/s-cost-tagung2012.htm.

Hungerbühler-Räber, M., \& Keller-Schuhmacher, K. (2003, October). Salutogenese und Kohärenzsinn. Was bedeuten diese Konzepte für die Praxis der pädagogisch sozial orientierten Angebote im Frühbereich? In Paper presented at the 8. International Annual Convention of the GAIMH, St. Gallen, Switzerland.

Jenny, G., Inauen, A., Brauchli,R., Füllemann, D., Müller, F., \& und Bauer, G. (2011). Projekt SWiNG-Schlussbericht der Evaluation. In Zusammenarbeit mit dem Winterthurer Institut für Gesundheitsökonomie, ZHAW. Im Auftrag und unter Mitwirkung von Gesundheitsförderung Schweiz und dem Schweizerischen Versicherungsverband (SVV).

Jurt, L., \& Nieuwenboom, W. (2004): “zwäg und stark" Evaluation eines schulischen Gesundheitsförderungsprojektes. Schlussbericht, Brugg: FHNW. Retrieved from https://forsbase.unil.ch/project/ study-public-detail/10656/.

Keller-Schuhmacher, K. (2004). Wie entsteht Gesundheit? Das Konzept der Salutogenese. Bulletin der Gesundheitsförderung Baselland, 1(2004), 4-6.

Keller-Schuhmacher, K. (2005). Salutogenese in der MütterVäterberatung: Von der grauen Theorie zum Grün des Lebens goldnem Baum? Zeitschrift des Schweizerischen Verbandes der Mütterberaterinnen "Click", 46, 23-28.

Kraemer, B., Wittmann, L., Jenewein, J., Maier, T., \& Schnyder, U. (2009). Is the stressor criterion dispensable? A contribution to the criterion A debate from a Swiss sample of survivors of the 2004 tsunami. Psychopathology, 42(5), 333-336.

Kraft, U., Udris, I., Mussmann, C., \& Muheim, M. (1994). Gesunde Personen-salutogenetisch betrachtet. Eine qualitative Untersuchung. Zeitschrift für Gesundheitspsychologie, 2, 216-239.

Lang, T., Hauser, R., Schlump, R., Klaghofer, R., \& Buddeber, C. (2000). Psychische Komorbidität und Lebensqualität von Patienten mit morbider Adipositas und Wunsch nach Gastric banding. Schweizerische Medizinische Wochenschrift, 130, 739-748.

Märki, A., Lattmann, U. P., \& Strittmatter, A. (2005). Lehrberuf und Gesundheit: Vom Problemansatz zur Ressourcenperspektive. Aarau: Netzwerk Bildung \& Gesundheit.

Mattig, T. (2014). Autonomie als Herausforderung für die Gesundheitsförderung (Gesundheitsförderung Schweiz, Arbeitspapier 19). Retrieved from Gesundheitsförderung Schweiz website: http:// gesundheitsfoerderung.ch/assets/public/documents/1_de/d-ueberuns/5-downloads/Arbeitspapier_019_GFCH_2014-01_-Autonomie.pdf.

Meier Magistretti, C., \& Luyben, A. (2012). Salutogenese am Lebensanfang. Hebamme.ch, 110(7-8), 37.

Meister, S. D., \& Haug, H.-J. (2004). Ressourcen schizophrener Patienten. Validitätsprüfung des Erhebungsbogens zur Erfassung gesunder Anteile. Der Nervenarzt, 75, 467-474. doi:10.1007/ s00115-003-1597-z.

Meyer, K. (Ed.). (2009). Gesundheit in der Schweiz. Nationaler Gesundheitsbericht 2008. Bern: Verlag Hans Huber.
Moreau-Gruet, F. (2013). Monitoring zur psychischen Gesundheit-mit Fokus "Ältere Menschen"und "Stress am Arbeitsplatz". Aktualisierung 2013 (Gesundheitsförderung Schweiz Arbeitspapier 2). Retrieved from Gesundheitsförderung Schweiz website: http:// www.obsan.admin.ch/bfs/obsan/de/index/05/ publikationsdatenbank.html?publicationID $=4724$.

Nussbaum, M., \& Sen, A. (1993). Capability and well-being. In A. Sen \& M. Nussbaum (Eds.), The quality of life (pp. 30-53). Oxford: Clarendon.

Pielot, A. (2009). Salutogenese im Pflegeprozess: Die Wirksamkeit der salutogenetischen Ressourcenförderung in den täglichen Pflegemaßnahmen. Saarbrücken: VDM Verlag.

Public Health Schweiz. (2012). Positionspapier, Gesundheitsförderung im frühen Kindesalter. Bern.

Reuter, H. (2006). Bewertung der Partizipation und des Empowerments von Mitarbeitenden bei der Entwicklung und Evaluation neuer Arbeitszeitmodelle. Wirtschaftspsychologie, 2(3), 64-71.

Rimann, M., \& Udris, I. (1997). Subjektive Arbeitsanalyse: der Fragebogen SALSA. In Stohm, O. (Ed) Unternehmen arbeitspsychologisch bewerte. Schriftenreihe Mensch, Technik, Organisation, Bd 10. Zürich: vdf Hochschulverlag, pp. 281-298.

Rolli-Salathé, C., \& Elfering, A. (2013). A health- and resourceoriented perspective on NSLBP. ISRN Pain, 2013, 1-19. doi:10. 1155/2013/640690.

Schlegel, M. (2004). Die therapeutische Arbeit am Sinn: Weg zur Stärkung der selbstheilenden Kräfte am Beispiel der Analytischen Psychologie von C. G. Jung. Psychotherapie Forum, 12, 36-47.

Schnyder, U. (2000). Die psychosozialen Folgen schwerer Unfälle. Darmstadt: Steinkopff.

Schnyder, U., Büchi, S., Mörgeli, H. P., Sensky, T., \& Klaghofer, R. (1999). Sense of coherence-A mediator between disability and handicap? Journal of Psychotherapy and Psychosomatics, 68, $102-110$

Schnyder, U., Moergeli, H., Klaghofer, R., Sensky, T., \& Buchi, S. (2003). Does patient cognition predict time off from work after life-threatening accidents? American Journal of Psychiatry, 160, 2025-2031.

Schnyder, U., Moergeli, H., Klaghofer, R., \& Buddeberg, C. (2001). Incidence and prediction of PTSD symptoms in severely injured accident victims. American Journal of Psychiatry, 158, 594-599.

Schnyder, U., Moergeli, H., Trentz, O., Klaghofer, R., \& Buddeberg, C. (2001). Prediction of psychiatric morbidity in severely injured accident victims at one-year follow-up. American Journal of Respiratory and Critical Care Medicine, 164, 653-656.

Schwendimann, M. (2013): Das Belastungserleben von Pflegenden in spezialisierten Wohnformen für Menschen mit Demenz und traditionellen Wohnformen. Eine vergleichende Analyse. Bern: berner Fachhochschule, Institut Alter.

Semmer, N. K., Jacobshagen, N., \& Meier, L. L. (2006). Arbeit und (mangelnde) Wertschätzung. Wirtschaftspsychologie, 2(3), 87-95.

Sollberger, D., Byland, M., \& Widmer, G. (2007). Biographische Identität zwischen Stigma und Tabu. Kinder psychisch kranker Eltern. In V. Mottier \& L. von Mandach (Eds.), ntegration und Ausschluss in Medizin, Psychiatrie und Sozialhilfe in der Schweiz: Zwischen Pflege, Stigmatisierung und eugenischen Konzepten. NFP 51 (pp. 132-143). Zürich: Seismo Verlag.

Sommer, I., \& Ehlert, U. (2004). Adjustment to trauma exposure: Prevalence and predictors of posttraumatic stress disorder symptoms in mountain guides. Journal of Psychosomatic Research, 57(4), 329-335.

Stamm, H., Lamprecht, M., \& Wiegand, D. (2014). Monitoring zum Thema Gesundes Körpergewicht-Aktualisierung 2014 (Gesundheitsforderung Schweiz Arbeitspapier 20). Retrieved from Gesundheitsförderung Schweiz website: http:// gesundheitsfoerderung.ch/assets/public/documents/1_de/d-ueberuns/5-downloads/Arbeitspapier_020_GFCH_2014-06_-_Monitor ing_Gesundes_Koerpergewicht_2014.pdf. 
Süss, D., von Arx, C., \& Marxer, M (2002): Kommunikationsstrategien in der Gesundheitsförderung. Eine Studie zur optimalen Gestaltung von Botschaften in Gesundheitsförderungskampagnen. Schlussbericht im Auftrag von Gesundheitsförderung Schweiz. Zürich: Hochschule für angewandte Psychologie.

Tamcan, Ö., Bantli, S., Abel, T., \& Barth, J. (2010). Bewältigungsressourcen bei Rückenschmerzen: ein neues Erhebungsinstrument für die therapeutische Praxis. Zeitschrift für Medizinische Psychologie, 19, 21-29.

Udris, I. (1990). Organisationale und personale Ressourcen der Salutogenese-Gesund bleiben trotz oder wegen Belastung? Zeitschrift für die gesamte Hygiene, 36(1990), 453-455.

Udris, I. (1993). Gesundheitsförderung durch Entwicklung und Verbesserung von Organisationsstrukturen. Sozial- und Präventivmedizin, 38(Suppl 2), S100-103.

Udris, I. (2006). Salutogenese in der Arbeit—Ein Paradigmenwechsel? Wirtschaftspsychologie, 2(3), 4-13.

Udris, I., Kraft, U., Muheim, M., Mussmann, C., \& Rimann, M. (1992). Ressourcen der Salutogenese. In: Schröder, H.; Reschke, K. (Hrsg.) Psychosoziale Prävention und Gesundheitsförderung (S. 85-103). Regensburg: Roderer.

Udris, I., Kraft, U., Mussmann, C., \& Rimann, M. (1992). Arbeiten, gesund sein und gesund bleiben: Theoretische Überlegungen $\mathrm{zu}$ einem Ressourcenkonzept. In: Udris, I. (Hrsg.) Arbeit und Gesundheit. Psychosozial, Band 52 (S. 7-21). Weinheim: Psychologie Verlags Union.

Udris, I., \& Rimann, M. (1999). SAA und SALSA: Zwei Fragebögen zur subjektiven Arbeitsanalyse. In H. Dunckel (Ed) Handbuch psychologischer Arbeitsanalyseverfahren. Zurich: vdf, 397-420.

Udris, I., Rimann, M., \& Thalmann, K. (1994). Gesundheit erhalten, Gesundheit herstellen: Zur Funktion salutogenetischer Ressourcen. In: B. Bergmann, \& P. Richter (Hrsg.) Die Handlungsregulationstheorie-Von der Praxis einer Theorie (S. 191-208). Göttingen: Hogrefe.

Vogt, K., Jenny, G. J., \& Bauer, G. F. (2013). Comprehensibility, manageability and meaningfulness at work: Construct validity of a scale measuring work-related sense of coherence. SA Journal of Industrial Psychology, 39(1), 1-8. doi:10.4102/sajip.v39i1.1111.

Wehner, T., \& Richter, P. G. (Eds.). (2006). Salutogenese in der Arbeit [Special issue]. Wirtschaftspsychologie, 2/3.

Wettstein, F. (2008). Gesundheistförderung und Prävention-ein Beitrag zur Klärung des oft diskutierten Verhältnisses unter besonderer Berücksichtigung der Suchtthematik. Abhängigkeiten, 2008(4), 41-51.

Wettstein, F. (2009). Die salutogenetische Perspektive in der Suchtprävention mit Kindern und Jugendlichen. Paper presented at the Forum für Suchtfragen. Basel, Switzerland: Gesundheitsdepartement Basel-Stadt.

Wettstein, F. (2014). Das doppelte Kontinuum des Mental Healthsozial ausbalanciert oder schief? Public Health Conference 2014, FHNW Olten, Key Note, August 21th. Retrieved from http://sph14. organizers-congress.ch/downloads/presentations/Keynotes/ KeyNotes_Wettstein.pdf.

White, J., Schouten, M., Berg, M., \& Meier Magistretti C. (2014): Stakeholder engagement and the diffusion of childbirth knowledge: experiences of the COST project IS0907: Optimizing childbirth through Europe. Poster presented at the Brussels Cost Conference of April 9th-10th, Retrieved from http://optimise2014.exordo.com/ data/abstract_book.pdf.

Wittmann, L., Moergeli, H., Martin-Soelch, C., Znoj, H., \& Schnyder, U. (2008). Comorbidity in posttraumatic stress disorder: a structural equation modelling approach. Comprehensive Psychiatry, 49(5), 430-440. doi:10.1016/j.comppsych.2008.02.004.

Wydler, H., Kolip, P., \& Abel, T. (Eds.). (2000). Salutogenese und Kohärenzgefühl. Grundlagen, Empirie und Praxis eines gesundheitswissenschaftlichen Konzepts (4th ed.). Bielefeld: Juventa.

Wydler, H., Mohler-Kuo, M., \& Gutzwiller, F. (2007). Elterliche Erziehungsstile und Eltern-Kind-Beziehungen-Ihr Einfluss auf die Gesundheit. Netzbrief Bildung \& Gesundheit, 5, 12-14.

Zeyer, A. (1997). Salutogenese und Pathogenese. Ein Paradigmenwechsel aus der Perspektive der modernen Physik. Sozial- und Präventivmedizin, 42, 380-384.

Znoj, H. J., \& Lude, P. (2002). Regulation of emotion and psychological symptoms in people with spinal cord injury. Swiss Journal of Psychology, 61(4), 203-210.

Zölch, M., Greiwe, S., \& Semling, C. (2005): Die Situation der Assistierenden und wissenschaftlichen Mitarbeitenden an Schweizer Fachhochschulen. Ergebnisse einer schweizweiten Befragung. Olten: Fachhochschule Nordwestschweiz FHNW.

Zwinggi, S., Roth, C., \& Schelling, H.R. (2006): Spiritualität in der stationären Alterspflege. Unveröffentlichter Bericht. Zürich: Universität Zürich, Zentrum für Gerontologie. 